\title{
ECONOMICS
}

\section{REGIONAL VARIATION IN CARBON EMISSIONS AND ITS DRIVING FORCES IN CHINA: AN INDEX DECOMPOSITION ANALYSIS}

\author{
by
}

Shu Yang

School of Management

University of Science and Technology of China

\section{Dingtao Zhao \\ School of Management}

University of Science and Technology of China

\author{
Yanrui Wu \\ Business School \\ University of Western Australia
}

Jin Fan

School of Management

University of Science and Technology of China 


\title{
REGIONAL VARIATION IN CARBON EMISSIONS AND ITS DRIVING FORCES IN CHINA: AN INDEX DECOMPOSITION ANALYSIS
}

\author{
Shu Yang ${ }^{1}$, Dingtao Zhao ${ }^{1}$, Yanrui Wu ${ }^{2}$ and Jin Fan $^{1}$
}

\section{DISCUSSION PAPER 13.34}

\begin{abstract}
This paper aims to investigate the factors affecting carbon emissions from the perspective of residential energy consumption. Specifically, through an index decomposition analysis (IDA), it examines the influence of social and economic factors on household carbon emissions in China's provinces. The results show that $\mathrm{CO}_{2}$ emissions associated with household consumption continued to grow during the decade of 2000-2010. In general, per capita consumption expenditure and the share of energy consumption expenditure in total consumption spending are two main factors contributing to an increase in residential carbon emissions, while the change of energy consumption structure and energy price mitigated the growth of carbon emissions. However, there are considerable regional differences. Therefore, Chinese government must consider the substantial contribution of residential consumption to carbon emissions when it aims to expand domestic consumption.
\end{abstract}

Key words: Residential energy consumption; regional differences; China

\footnotetext{
${ }^{1}$ School of Management, University of Science and Technology of China. ${ }^{2}$ Business School, University of Western Australia (The corresponding author: yanrui.wu@uwa.edu.au). The authors acknowledge the National Natural Science Foundation of China $(71171183,71121061)$ for its generous financial support. They also thank an anonymous referee and Zhongxiang Zhang for their helpful comments.
} 


\section{INTRODUCTION}

The dramatic economic development and increase in disposable income have helped Chinese citizens to obtain a quality of life characterized by high quality food, comfortable living, healthcare and appreciation of western lifestyle (Hubacek et al., 2009). Accordingly, residents' energy consumption habit and preference shift due to the popularization of electric appliances and private transportation vehicles has resulted in a continual increase in total residential energy consumption (Figure 1). Although the share of residential energy consumption in total final energy consumption was relatively small compared to industry in China in 2010 (Figure 2), it will continue to increase with the economic development and the rise of household energy consumption (Zhou et al., 2009). In recent years, many studies have shown that the growth rate of carbon emissions by household consumption exceeded that of industry, and residential consumption has become a major growth point of energy consumption and carbon emissions (Schipperd, 1989; Kim, 2002; Linden, 2006; Pachauri and Spreng, 2002; Reinders, 2003; Bin and Dowlatabadi, 2005; Steg, 2008). IPCC (2001) also suggested the change in consumption patterns as a possible approach to alleviate the effects of climate change. Thus, residential energy consumption is an important field for energy conservation apart from industrial production. Understanding the drivers for the increase of carbon emissions from the perspective of residential energy consumption has important implications for China’s future energy and carbon emission policy. 


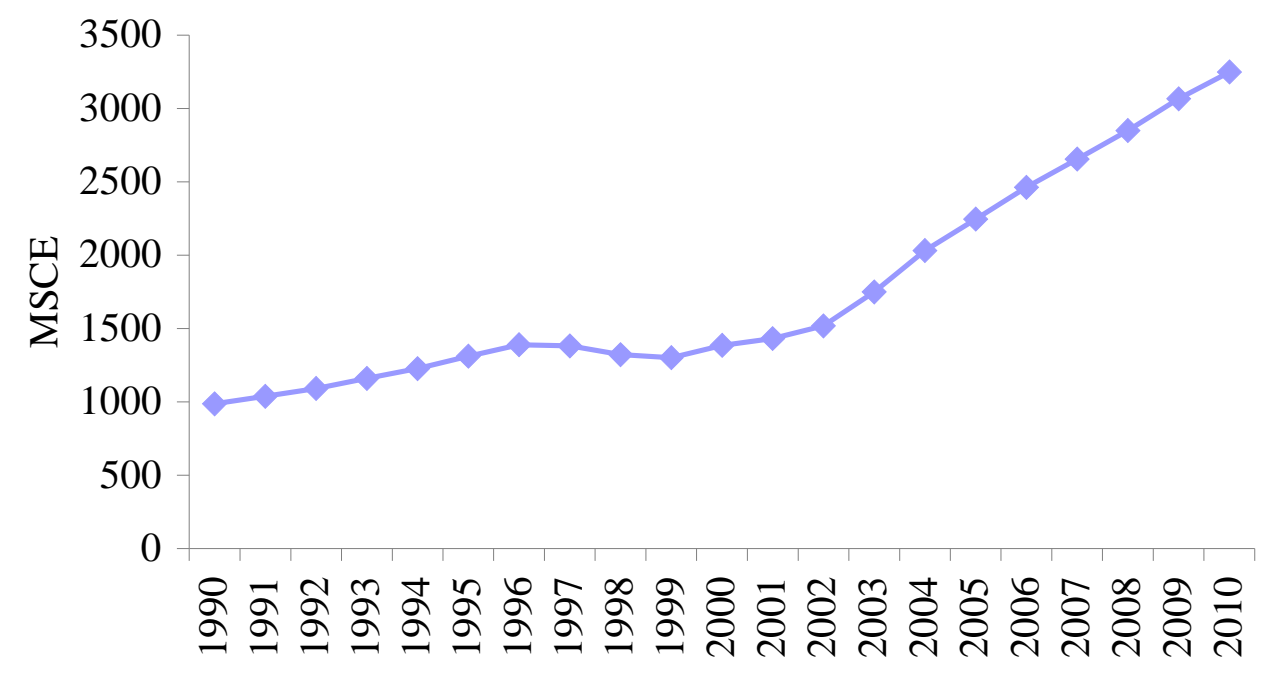

Sources: China Statistical Yearbooks (1991-2011).

Notes: MSCE is short for megatons of standard coal equivalent.

Figure 1. Residential energy consumption in China, 1990-2010

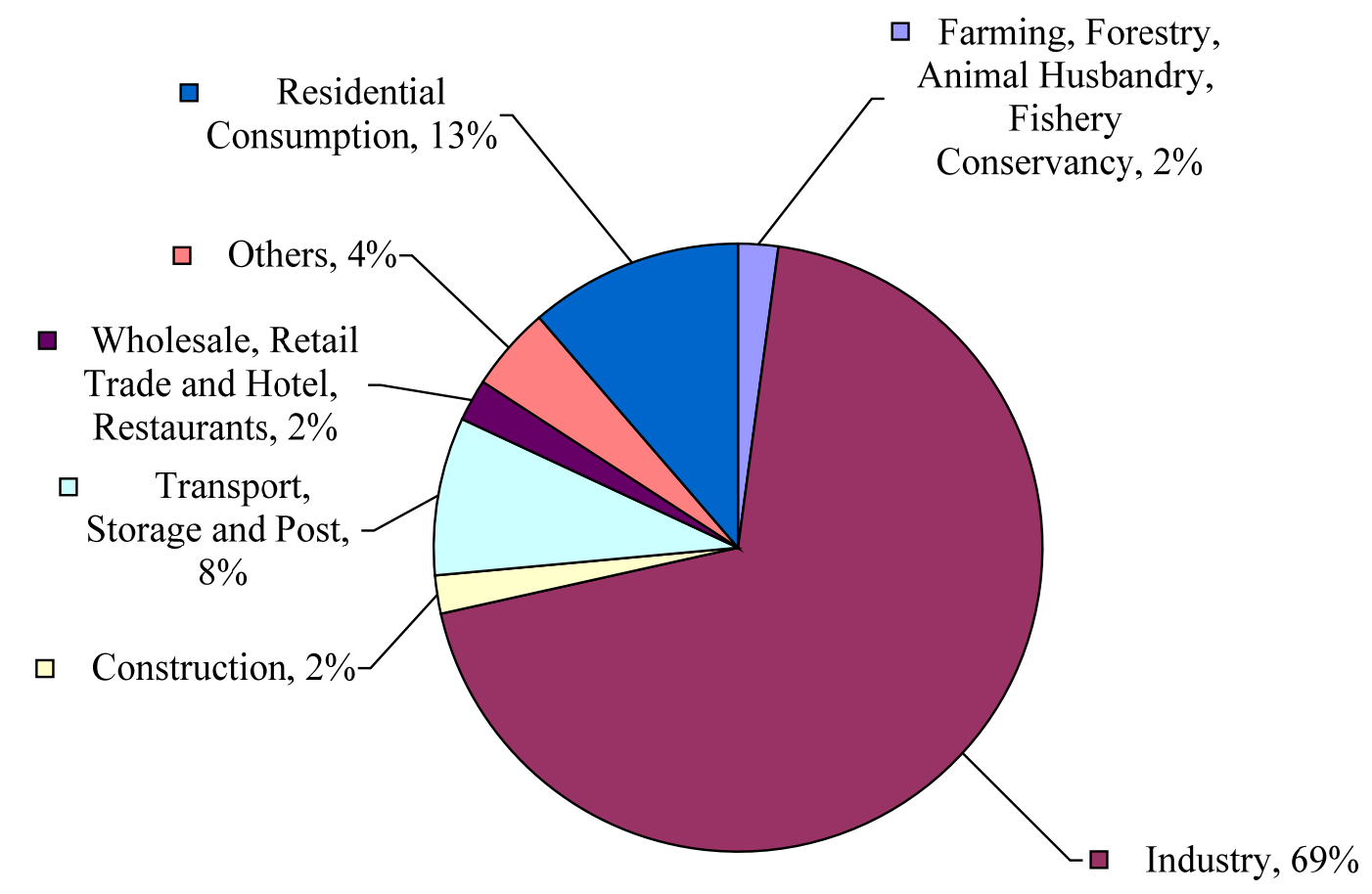

Sources: China Energy Statistical Yearbook 2011.

Figure 2. China's final energy consumption by categories, 2010 
In this paper residential carbon emissions in China's provinces were estimated from the final residential energy consumption and decomposed into several components using a log-mean Divisia index (LMDI) framework. In addition, since there are significant regional differences in climate conditions, natural resource endowment, energy-saving technologies, economic development level and consumption level, this research examines the influence of these socio-economic factors on household carbon emissions during the period of 2000-2010. This analysis is of great significance for establishing a local emission reduction strategy as well as realizing regional low-carbon economy development. The empirical analysis is undertaken in two stages. First, $\mathrm{CO}_{2}$ emissions associated with residential energy consumption are calculated using the methodology of inventory composition developed by IPCC (2006). Second, carbon emission change is decomposed into several components in order to identify the main determinant. The present study would help guide the household consumption behavior toward a sustainable low-carbon mode as China moves from a middle-income country toward a high income society.

The rest of this paper is organized as follows. Section 2 reviews the existing studies of carbon emissions associated with residential energy consumption. Section 3 describes the methodology of this study and the data source. Section 4 presents the empirical results of this study. Section 5 provides concluding remarks. 


\section{LITERATURE REVIEW}

There is a large body of the literature focusing on total or industrial energy consumption and related carbon emissions. For example, Hasanbeigi et al. (2012) analysed the energy use of and output from seventeen industry subsectors in California and performed decomposition analysis to assess the influence of different factors on California's industry energy use. Andreoni and Galmarini (2012) used a decomposition technique to investigate the contribution of the main factors influencing the energy-related carbon dioxide emissions in Italy, and considered five economic sectors, namely, the agricultural sector, the industrial sector, the electricity and heat production sector, water and gas sector, the transport sector, and the services sector. Research in the field of residential energy consumption and related carbon emissions, however, is much less prevalent. Residential energy consumption is defined as the consumption of coal, petroleum, natural gas, heat and electricity by households, which is also called as "direct energy consumption” (Weber and Perrels, 2000). The carbon emissions associated with each form of energy can be readily derived using established “carbon coefficients”.

Schipper et al. (1989) conducted one of the earliest studies focusing on residential energy consumption. Their research led them to conclude that approximately $45-55 \%$ of total energy use was influenced by consumer activities. Vringer and Blok (1995) estimated the direct and indirect energy consumption of households in the Netherlands, and their results showed that 54\% of energy consumption of household came from direct use. Pachauri and Spreng (2002) estimated direct and indirect energy 
requirements of households in India, and concluded that total residential energy consumption accounted for $75 \%$ of total energy consumption in India. In addition to the above research, there are many similar studies such as Reinders et al. (2003), Pachauri (2004), Bin and Dowlatabadi (2005), Cohen et al. (2005), and Park and Heo (2007).

Residential energy consumption and related carbon emissions in China have also attracted scholars’ attention. Wei et al. (2007) first quantified the direct and indirect energy requirements and related carbon emissions of China's urban and rural residents during 1999 to 2002. They found that 26\% of China’s total energy consumption and $30 \%$ of its carbon emissions were the "consequence of residents" lifestyles and economic activities. Liu et al. (2011) estimated China's carbon emissions from urban and rural households during 1992-2007. Their results showed that the direct and indirect $\mathrm{CO}_{2}$ emissions from household consumption accounted for more than $40 \%$ of total carbon emissions from primary energy utilization. Feng et al. (2011) analyzed and compared the impact of consumption by urban and rural households on energy use and $\mathrm{CO}_{2}$ emissions among different regions and income levels in China. It can be seen that most of these studies focus on the estimates of carbon emissions associated with residential energy consumption, but the driving factors of residential consumption are hardly considered.

As for the methods, studies of $\mathrm{CO}_{2}$ emissions mainly rely on the decomposition techniques, which allow analysts to identify the determinants of emission changes over 
time. Among the decomposition methods, scholars have identified logarithmic mean Divisia index (LMDI) as the most appropriate method for the decomposition of emission changes (Ang, 2004; Ang and Liu, 2007; Ang et al., 2003 ). Reasons for this preference include the theoretical foundation of LMDI and its adaptability in applications. To be specific, among the Divisia and Laspeyres decomposition methods, the former can eliminate the residual item but the latter cannot (Ang, 2004). Ang et al. (2003) also demonstrated that in terms of application and flexibility, the LMDI method has some advantages over the other decomposition methods (such as RMCI, RLI, and Shapley), especially in the field of energy policy studies. LMDI is also fully documented with applications in many countries. Among the studies, Wang et al. (2005) analyzed the change of aggregated $\mathrm{CO}_{2}$ emissions in China from 1957 to 2000 and found that China had achieved a considerable reduction in its $\mathrm{CO}_{2}$ emissions mainly because of the decline in energy intensity. Zha et al. (2010) examined the driving forces of residential carbon emissions in urban and rural China and found that energy intensity contributed most to the decline of residential $\mathrm{CO}_{2}$ emissions while the income effect is responsible for the increase of residential $\mathrm{CO}_{2}$ emissions.

This study differs from the existing studies by providing a comprehensive analysis of the drivers of China's residential energy consumption growth. It also investigates the determinants not considered by existing research. In addition, this study considers regional differences and analyzes the carbon emission changes in Chinese provinces. 


\section{METHOD AND DATA SOURCES}

\subsection{Conceptual and modeling issues}

$\mathrm{CO}_{2}$ emissions associated with residential energy consumption are calculated using the method for inventory composition developed by IPCC (2006). It is related to the quantity of residential energy consumption, energy mix and $\mathrm{CO}_{2}$ emissions factors. Symbolically,

$$
C_{i}=\sum_{j} \sum_{k} f_{k} E_{i, j, k}
$$

Where

$i$ : 30 provinces in China;

$j$ : The urban $(j=0)$ and rural $(j=1)$ residents;

$k$ : The type of energy;

$f_{k}: \mathrm{CO}_{2}$ emission factor of energy $k$;

$C_{i}$ : $\mathrm{CO}_{2}$ emissions from residential energy consumption of region $i$;

$E_{i, j, k}$ : Final energy consumption of fuel $k$ of type $j$ resident in region $i$.

As noted in section 2, we shall apply the LMDI approach to analyze the driving forces of residential $\mathrm{CO}_{2}$ emissions. The set of determinants used in this study is summarized in the following decomposition identity.

$$
C_{i}=\sum_{j} \sum_{k}\left(\frac{C_{i, j, k}}{E_{i, j, k}} \bullet \frac{E_{i, j, k}}{E_{i, j}} \bullet \frac{E_{i, j}}{L_{i, j}^{e}} \bullet \frac{L_{i, j}^{e}}{L_{i, j}} \bullet \frac{L_{i, j}}{P_{i, j}} \bullet \frac{P_{i, j}}{P_{i}} \bullet P_{i}\right)
$$

Where

$C_{i, j, k}: \mathrm{CO}_{2}$ emissions from residential consumption by fuel $k$ of type $j$ resident in 
region $i$;

$E_{i, j, k}$ : Final energy consumption of fuel $k$ of type $j$ resident in region $i$;

$E_{i, j}$ : Total energy consumption of type $j$ resident in region $i$;

$L_{i, j}^{e}$ : Consumption expenditure of energy of type $j$ resident in region $i$;

$L_{i, j}$ : Total consumption expenditure of type $j$ resident in region $i$;

$P_{i, j}$ : Population of type $j$ resident in region $i$;

$P_{i}:$ Population in region $i$

Define:

$$
f_{i, j, k}=\frac{C_{i, j, k}}{E_{i, j, k}} ; s_{i, j, k}=\frac{E_{i, j, k}}{E_{i, j}} ; p e_{i, j}=\frac{E_{i, j}}{L_{i, j}^{e}} ; \varphi_{i, j}=\frac{L_{i, j}^{e}}{L_{i, j}} ; v_{i}=\frac{L_{i, j}}{P_{i, j}} ; d_{i}=\frac{P_{i, j}}{P_{i}}
$$

Equation (2) can be rewritten as follows:

$$
C_{i}=\sum_{j} \sum_{k}\left(f_{i, j, k} \bullet s_{i, j, k} \bullet p e_{i, j} \bullet \varphi_{i, j} \bullet v_{i, j} \bullet d_{i} \bullet P_{i}\right)
$$

Where:

$f_{i, j, k}$ is $\mathrm{CO}_{2}$ emission factor of energy $k$;

$S_{i, j, k}$ is the share of consumption expenditure of energy $k$ in total consumption expenditure of type $j$ resident in region $i$;

$p e_{i, j}$ is the quantity of residential energy consumption per unit of energy consumption expenditure of type $j$ resident in region $i$; the reciprocal of $p e_{i, j}$ refers to the price of energy;

$\varphi_{i, j}$ is the share of energy consumption expenditure in total consumption expenditure of type $j$ resident in region $i$; 
$V_{i, j}$ is per capita consumption expenditure of type $j$ resident in region $i$;

$d_{i}$ is the urban and rural structure of population in region $i$.

For the calculation of $\mathrm{CO}_{2}$ emission coefficients, the carbon emissions from electricity use should take the fossil fuels used during the production, processing and final consumption into consideration. China's electricity is mainly generated from thermal power, hydropower and nuclear power. We use Equation (4) to calculate the $\mathrm{CO}_{2}$ emission coefficient of electricity:

$$
\rho_{e}=\frac{\sum_{j=1}^{3} \sum_{i=1}^{3} \omega_{i, j} \rho_{i}}{Q}
$$

$\omega_{i, j}$ represents the direct consumption of the primary energy $i$ by power sector $j$ . $\rho_{i}$ represents the $\mathrm{CO}_{2}$ emission coefficient of the primary energy $i$. The primary energies include coal, petroleum and natural gas and the power sectors include thermal power, hydropower and nuclear power sectors. $Q_{\text {represents the total }}$ electricity generated. Equation (5) shows the method to calculate the $\mathrm{CO}_{2}$ emission coefficient of heat:

$$
\rho_{h}=\frac{\sum_{i=1}^{3} \varphi_{i} \rho_{i}}{H}
$$

$\varphi_{i}$ represents the direct consumption of primary energy $i$ by heat sector and $H$ represents the total generated heat. 
Applying LMDI in its additive form, the change of $\mathrm{CO}_{2}$ emissions associated with residential energy consumption between two years ( $t$ and $t-1$ ) is decomposed as follows:

$$
\begin{aligned}
\Delta C_{i} & =C_{i}^{t}-C_{i}^{t-1} \\
& =\Delta C_{i, f_{i, j, k}}+\Delta C_{i, s_{i, j}}+\Delta C_{i, p e_{i, j}}+\Delta C_{i, \varphi_{i, j}}+\Delta C_{i, V_{i, j}}+\Delta C_{i, d_{i, j}}+\Delta C_{i, P_{i}}
\end{aligned}
$$

Where

$\Delta C_{i, f_{i, j, k}}$ : The contribution of change in $\mathrm{CO}_{2}$ emission factor;

$\Delta C_{i, s_{i, j}}$ : The contribution of change in energy consumption structure;

$\Delta C_{i, p e_{i, j}}$ : The contribution of change in energy price;

$\Delta C_{i, \varphi_{i, j}}$ : The contribution of change in the ratio of energy consumption expenditure in total consumption;

$\Delta C_{i, v_{i, j}}$ : The contribution of change in per capita consumption expenditure;

$\Delta C_{i, d_{i, j}}$ : The contribution of change in population structure;

$\Delta C_{i, P_{i}}$ : The contribution of change in population scale.

Each effect in the right side of Equation (6) can be computed through difference decomposition and seven computed equations (see Appendix for details). The $\mathrm{CO}_{2}$ emission coefficients of various kinds of energy are viewed as constant in most studies for their stability, so the effect of change in $\mathrm{CO}_{2}$ emission factor is equal to 0 in the decomposition analysis. Equation (6) can be simplified as follows:

$$
\begin{aligned}
\Delta C_{i} & =C_{i}^{t}-C_{i}^{t-1} \\
& =\Delta C_{i, s_{i, j}}+\Delta C_{i, p e_{i, j}}+\Delta C_{i, \varphi_{i, j}}+\Delta C_{i, v_{i, j}}+\Delta C_{i, d_{i, j}}+\Delta C_{i, P_{i}}
\end{aligned}
$$




\section{2 . Data sources}

The data sample covers the period of 2000-2010. Data for urban and rural residential energy consumption by provinces are taken from China Energy Statistical Yearbook for 2001-2011. Data of total population, urban and rural population, per capita consumption expenditure, energy consumption expenditure are all taken from China Statistical Yearbook for 2001-2011. As for the energy price, we use the "electric fuel price indices" in China Statistical Yearbook for 2001-2011 to represent different regions’ residential energy price. $\mathrm{CO}_{2}$ emission coefficients for oil, petroleum, gas are from the report by the Energy Research Institute of Chinese National Development and Reform Commission (2003). $\mathrm{CO}_{2}$ emissions for electricity and heat are calculated using the data of China Energy Statistical Yearbook for 2006-2008. We calculate the conversion rates of fossil fuels for heat and electric power and obtain the $\mathrm{CO}_{2}$ emissions coefficients.

\section{RESULTS AND DISCUSSION}

\section{1. $\mathrm{CO}_{2}$ emissions associated with residential energy consumption}

Table 1 shows the change of $\mathrm{CO}_{2}$ emissions associated with residential consumption in terms of total $\mathrm{CO}_{2}$ emissions from residential energy consumption, per capita $\mathrm{CO}_{2}$ emissions from residential energy consumption, per capita $\mathrm{CO}_{2}$ emissions from urban residential energy consumption and per capita $\mathrm{CO}_{2}$ emissions from rural residential energy consumption. It can be seen that total and per capita carbon emissions follow an 
upward trend, increasing from 326.61megatons and 0.26 tons to 670.53 megatons and 0.50 tons respectively, with the growth rates of $105 \%$ and $92.3 \%$ during $2000-2010$. It is worth noting the several sharp increases in the years of 2005 and 2007-2010.

Meanwhile, carbon emissions from urban and rural residents' consumption also showed a growing trend. Due to higher urban residents' consumption level, carbon emissions per capita from urban residential consumption were obviously higher than those of rural residents. More specifically, the period of 2000-2010 witnessed emissions from urban and rural residents rising from 0.36 and 0.20 t/person to 0.63 and $0.37 \mathrm{t} /$ person respectively. Considering the substantial increase of household carbon emissions in China during the past decade, it is worthwhile identifying the driving forces behind these changes.

Table 1 China's $\mathrm{CO}_{2}$ emissions from residential energy consumption, 2000-2010

\begin{tabular}{ccccc}
\hline Year & $\begin{array}{c}\text { Total } \mathrm{CO}_{2} \\
\text { Megatons) }\end{array}$ & $\begin{array}{c}\text { per capita } \mathrm{CO}_{2} \\
\text { (t/person) }\end{array}$ & $\begin{array}{c}\text { urban per capita } \\
\mathrm{CO}_{2} \text { (t/person) }\end{array}$ & $\begin{array}{c}\text { rural per capita } \\
\mathrm{CO}_{2} \text { (t/person) }\end{array}$ \\
\hline 2000 & 326.61 & 0.26 & 0.36 & 0.20 \\
2001 & 339.90 & 0.27 & 0.36 & 0.21 \\
2002 & 355.19 & 0.28 & 0.39 & 0.21 \\
2003 & 383.11 & 0.30 & 0.39 & 0.23 \\
2004 & 408.22 & 0.31 & 0.41 & 0.24 \\
2005 & 473.29 & 0.36 & 0.47 & 0.28 \\
2006 & 478.27 & 0.36 & 0.48 & 0.27 \\
2007 & 513.91 & 0.39 & 0.50 & 0.30 \\
2008 & 549.39 & 0.41 & 0.53 & 0.31 \\
2009 & 590.54 & 0.44 & 0.56 & 0.34 \\
2010 & 670.53 & 0.50 & 0.63 & 0.37 \\
\hline
\end{tabular}

Sources: Authors’ own calculation

Figure 3 shows the change of $\mathrm{CO}_{2}$ emissions from residents' energy consumption of China’s 30 provinces from 2000 to 2010 . It can be seen that there were obvious 
differences among different regions. The growth of $\mathrm{CO}_{2}$ emissions of Inner-Mongolia, Shandong, Guangdong, Heilongjiang were all more than 20 megatons, which were higher than other provinces, especially Guizhou, Hainan and Qinghai. In addition, Guizhou was the only province whose $\mathrm{CO}_{2}$ emissions from residential energy consumption decreased. These discrepancies indicated that it is worthwhile to identify the differences among regions.

\subsection{Overall analysis}

Based on the method described in Section 3, we investigate the change and its sources of China's residential carbon emissions during the period of 2000 to 2010. Table 2 shows the results of the decomposition analysis. It is found that the contributions of energy consumption structure, energy price, per capita consumption expenditure, and ratio of energy consumption expenditure in total consumption are much higher than those of population structure and population scale. Thus the former four played a more crucial role in China's total residential carbon emission increase. Additionally, it was found that the change of per capita consumption expenditure and population structure showed a positive effect on the growth of carbon emission throughout the analytical period, while the change of population scale and ratio of energy consumption expenditure in total consumption mainly exhibited a positive effect. A negative effect was revealed for the change of energy price. We will discuss these six driving factors one by one in detail. 


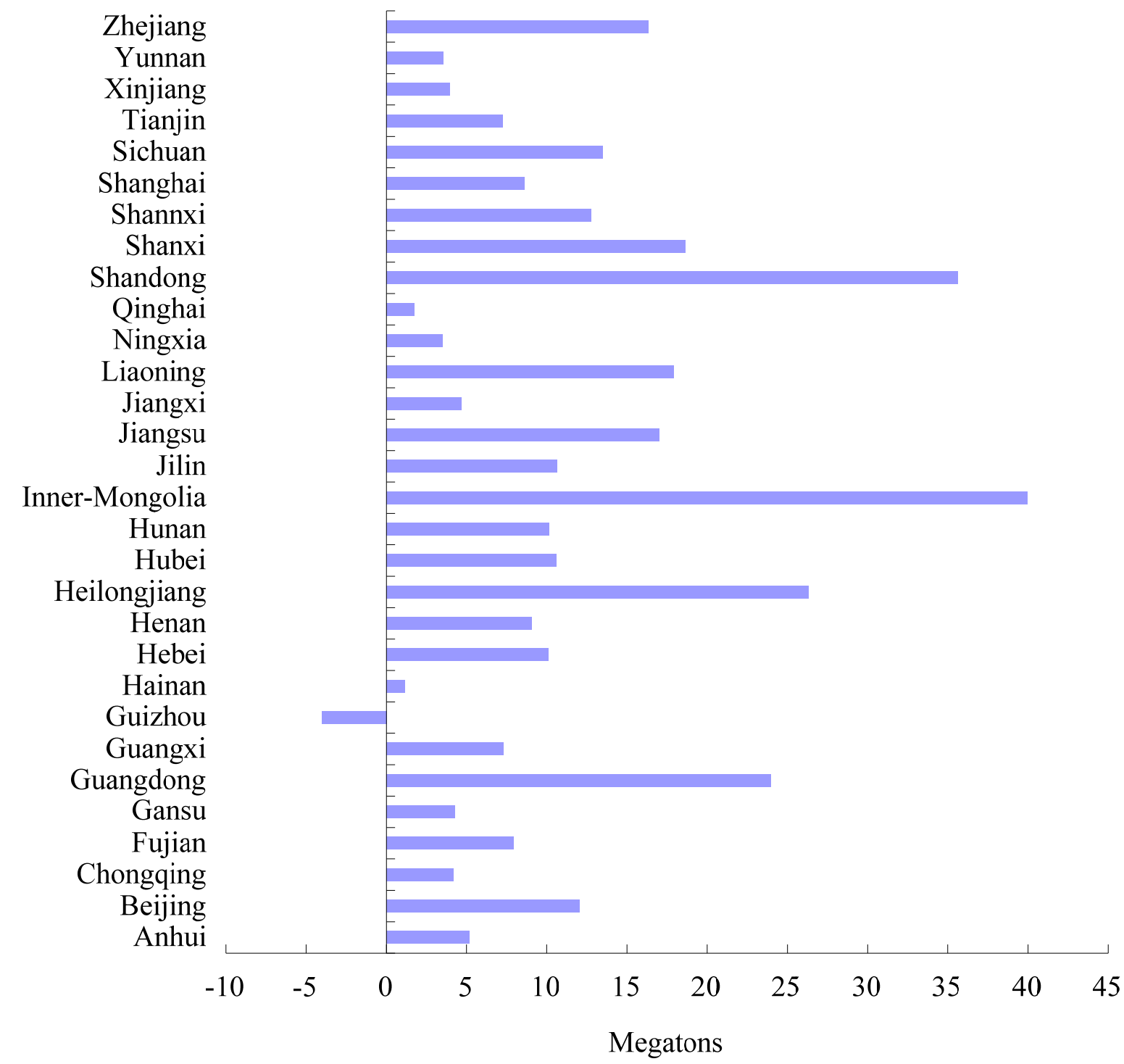

Sources: Authors' own calculation

Notes: The values indicate the changes of residential $\mathrm{CO}_{2}$ emissions between 2000 and 2010. Tibet is excluded due to missing data.

Figure 3. Regional $\mathrm{CO}_{2}$ emissions from residential energy consumption, 2000-2010.

The change of the energy consumption structure consistently showed a strong negative effect on $\mathrm{CO}_{2}$ emissions from residential energy consumption. It indicates that the structure of residential energy consumption was changing toward the optimization direction, which could be seen in Table 3. More specifically, energy consumption 
structure changed significantly during the years from 2000 to 2010, when the proportion of coal in the total energy consumption dropped significantly, decreasing from $52.3 \%$ to 28.7\%. On the contrary, the shares of natural gas, heat and electricity went up from 4.0\%, $7.3 \%$ and $16.4 \%$ to $12.6 \%, 9.6 \%$ and $26.3 \%$ respectively. In particular, electricity experienced the largest rise. Because China's production of electricity and heat mainly relies on coal, non-fossil energies such as wind power, nuclear power, biomass energy, and solar energy should be encouraged. In addition, among the fossil fuels, the relative clean energy, gas, still accounts for only a small proportion in domestic primary energy consumption. Therefore, promoting the development of gas industries as well as gas consumption is a crucial issue in the short run for China.

Table 2 Decomposition of $\mathrm{CO}_{2}$ emissions (unit: megatons).

\begin{tabular}{cccccccc}
\hline $\begin{array}{c}\text { Time } \\
\text { periods }\end{array}$ & $\Delta C_{s}$ & $\Delta C_{p e}$ & $\Delta C_{V}$ & $\Delta C_{d}$ & $\Delta C_{P}$ & $\Delta C_{\varphi}$ & $\Delta C$ \\
\hline $2000-2001$ & -14.16 & -8.23 & 17.07 & 1.56 & 0.15 & 16.89 & 13.29 \\
$2001-2002$ & -8.50 & -9.69 & 31.97 & 2.12 & 2.06 & -2.67 & 15.30 \\
$2002-2003$ & -26.22 & -19.43 & 25.08 & 3.46 & -3.18 & 48.21 & 27.92 \\
$2003-2004$ & -9.15 & -25.84 & 42.24 & 1.84 & 6.92 & 9.08 & 25.11 \\
$2004-2005$ & -26.22 & -30.45 & 55.25 & 2.35 & 5.20 & 58.95 & 65.07 \\
$2005-2006$ & -48.66 & -21.71 & 45.67 & 2.72 & 2.74 & 24.23 & 4.98 \\
$2006-2007$ & -84.30 & -11.12 & 67.68 & 2.69 & 3.18 & 57.50 & 35.64 \\
$2007-2008$ & -34.93 & -24.44 & 64.46 & 3.17 & 4.66 & 22.54 & 35.48 \\
$2008-2009$ & -28.85 & 8.06 & 49.56 & 2.69 & 4.03 & 5.66 & 41.15 \\
$2009-2010$ & -24.84 & -23.76 & 58.84 & 5.98 & 3.87 & 59.90 & 79.99 \\
average & -30.58 & -16.66 & 45.782 & 2.858 & 2.963 & 30.029 & 34.39 \\
\hline
\end{tabular}

Sources: Authors' own calculation

Notes:

$\Delta C_{s}$ : The effect of energy consumption structure;

$\Delta C_{p e}$ : The effect of energy price; 
$\Delta C_{v}$ : The effect of per capita consumption expenditure;

$\Delta C_{d}$ : The effect of population structure;

$\Delta C_{P}$ : The effect of population scale;

$\Delta C_{\varphi}$ : The effect of the ratio of energy consumption expenditure in total consumption;

$\Delta C$ : The total effect (China's total residential carbon emission increase).

Table 3 China's residential energy consumption structure (\%)

\begin{tabular}{cccccc}
\hline Time & Coal & Petroleum & Gas & Heat & Electricity \\
\hline 2000 & 52.3 & 20.0 & 4.0 & 7.3 & 16.4 \\
2001 & 49.9 & 20.1 & 5.0 & 7.2 & 17.8 \\
2002 & 48.5 & 20.5 & 5.2 & 7.6 & 18.3 \\
2003 & 47.9 & 20.5 & 5.0 & 8.3 & 18.3 \\
2004 & 45.2 & 22.2 & 5.6 & 8.8 & 18.2 \\
2005 & 42.2 & 21.1 & 6.1 & 10.2 & 20.4 \\
2006 & 38.6 & 21.9 & 7.3 & 10.3 & 21.9 \\
2007 & 33.4 & 23.3 & 9.3 & 9.6 & 24.4 \\
2008 & 31.6 & 21.9 & 10.7 & 10.1 & 25.6 \\
2009 & 30.3 & 22.3 & 10.5 & 10.2 & 26.7 \\
2010 & 28.7 & 22.7 & 12.6 & 9.6 & 26.3 \\
\hline
\end{tabular}

Sources : China Energy Statistical Yearbook (2001-2011).

The change in energy price consistently exhibited a strong negative effect. This contributed to the reduction of carbon emissions from residential energy consumption during the past decade; except for the period 2008-2009 with the corresponding contribution rates ranging from $-436.0 \%$ to $19.6 \%$. This phenomenon revealed that with the increase of energy prices residents reduced their energy consumption, which promoted the decrease of carbon emissions from household consumption through changing their lifestyles and consumption habits. In contrast, a decrease in energy price 
may lead to an increase in energy consumption and hence contribution to the increase of carbon emissions. This is particularly the case of China's rural areas in the earlier 2000s. Although China’s electricity price keeps increasing in most years during 20002010, the average electricity price in rural areas decreased due to the rural grid reconstruction and this in turn stimulated energy consumption there, increasing at a rate of 9\% per year for 2001-2005. Recently, the Chinese government’s implementation of the tiered residential electricity price scheme strengthened the effect of electricity price leverage on electricity consumption. Such policies encourage consumers to adopt conservation habits in order to reduce energy consumption and should be carried out actively.

The LMDI results showed that per capita consumption expenditure and share of energy consumption expenditure in total consumption were the two main driving factors in domestic carbon emissions from residential energy consumption. The main driver for the rapid rise of carbon emissions is the improvement of living standards, with the contribution values and contribution rates changing from 17.07 and $128.5 \%$ to 67.68 and $916.9 \%$ respectively for the ten year time period. This effect is even higher after 2003, with all the contribution values being higher than 40 . The share of energy consumption expenditure in total consumption is another important factor, whose contribution values and contribution rates vary from -2.67 and $-17.4 \%$ to 59.90 and 486.5\% respectively. This was due to the increasing consumption of energy intensive products (e.g. household appliances such as a fridge and air-conditioners) and 
transportation products (e.g. family vehicles), which led to a sharp rise of electricity consumption and oil fuel consumption respectively. Additionally, there is a growing trend for residents to choose vehicles with bigger engines, leading to a rapid increase of carbon emissions. Therefore, China needs to control the growth of transportation products and energy intensive appliances, improve the energy efficiency of energyintensive electrical equipment and introduce energy efficiency label management. Moreover, consumption and life style habits should be changed to encourage more use of public transport and purchase of low-emission cars.

The LMDI results also show that the positive effect of urbanization was small, with an average contribution value of 2.86. Because the consumption level and energy consumption quantity of urban residents is much higher than rural residents, urbanization promoted carbon emissions from residential consumption to increase to some extent. Although urbanization level rose from $36.22 \%$ to $49.68 \%$ in China during the past decade, the contribution of population structure change to residential carbon emissions was declining, which demonstrated that the effect of population structure change on carbon emissions was weakening as illustrated in Table 2.

The LMDI results further imply that population scale change had some positive effect on carbon emissions from residential energy consumption, with the average contribution value of 2.963. China's net population increase was around 700 million during the period from 2000 to 2010. However, the contribution of population scale change to 
carbon emissions, similar to that of population structure, was declining and the effect of population scale change on carbon emissions was weakening during 2000-2010.

\subsection{Regional comparative analysis}

Given the size of each province, we use the contribution rate of each effect, expressed in percentage terms, to reflect changes. Ningxia and Tibet are not included in regional analysis because of missing data. Additionally, it's worth noting that Guizhou's $\mathrm{CO}_{2}$ emission decreased during 2000-2010, which contradicts with other provinces. Figure 4 shows the contribution rate of the effects of energy consumption structure on $\mathrm{CO}_{2}$ emissions were markedly different among the provinces during 2000-2010. The values of all provinces except Guizhou, Inner-Mongolia and Shanxi were negative indicating a reduction in carbon emissions in these areas. In terms of the absolute values of the contribution rates of energy consumption structure, Xinjiang, Tianjin and Jiangsu were the top three provinces with the rates of $-571.0 \%,-278.0 \%$ and $-242.9 \%$ respectively. In contrast, Guangxi, Shanxi and Inner-Mongolia had the least effect. In particular in the latter two, their contribution values and rates were positive which illustrated that the energy consumption structure of these provinces was evolving toward high-carbon direction and should be adjusted urgently. These regions should strengthen the optimization of energy consumption structure, reduce the consumption of coal, and increase the consumption of non-fossil fuels. 


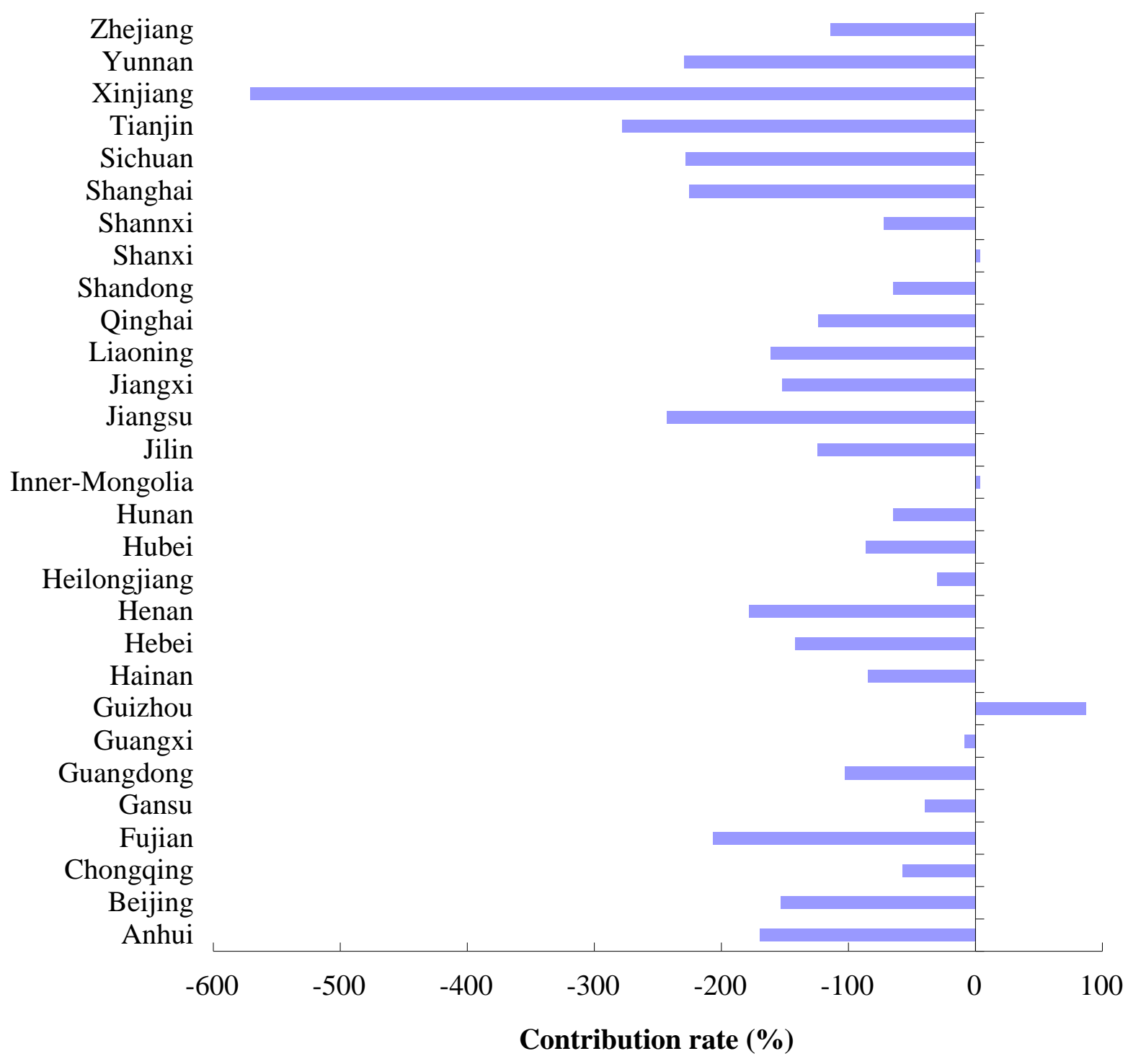

Sources: Authors' own calculation

Figure 4 The contribution rate of the change in energy consumption structure

The data in Figure 5 shows that the contribution rates of the effect of change in energy prices are different among the provinces. Consistently, all these rates except for Guizhou (its $\mathrm{CO}_{2}$ emission change is negative for 2000-2010) were negative and the energy price increase let to the carbon emission reduction in all provinces. Hebei, Xinjiang and Gansu were top three provinces with the biggest absolute values of negative contribution rates, where the decrease of carbon emissions caused by energy 
price played a significant role in the carbon reduction of local residential energy consumption. The absolute values of contribution rates of the three provinces are 223.1\%, 209.1\% and 157.3\% respectively. It's also worth noting that the contribution rate of energy price change for Guizhou is positive because the $\mathrm{CO}_{2}$ emission change of Guizhou for 2000-2010 is negative. Thus, the increase of energy price contributed to the decrease of $\mathrm{CO}_{2}$ emissions in Guizhou, with the contribution rate of $198.8 \%$. On the contrary, the effect of price was weaker in Zhejiang and Hainan, with the absolute values of contribution rates of $18.9 \%$ and $19.2 \%$ respectively. These provinces should reinforce the price adjustment effect to guide the residential energy consumption.

There were significant differences among these provinces concerning the contribution rates of the effect of change in residents’ per capita consumption expenditure during 2000-2010 (see Figure 6). Except for Guizhou all the rates were positive which means that residents’ per capita consumption expenditure drove carbon emission increases in all provinces. In terms of the effect of change in residents' per capita consumption expenditure, Hebei, Xinjiang and Yunnan were top three provinces with the biggest contribution rates, where the change in expenditure per capita caused an increase of local residents' carbon emissions. The absolute values of contribution rates of the three provinces are $447.1 \%, 391.3 \%$ and $360.6 \%$ respectively. Additionally, Guizhou was the only province with a negative contribution rate (-447.1\%) which was due to a decrease in $\mathrm{CO}_{2}$ emissions during the decade. The change in Guizhou's expenditure per capita was responsible for $\mathrm{CO}_{2}$ emission reduction there. 


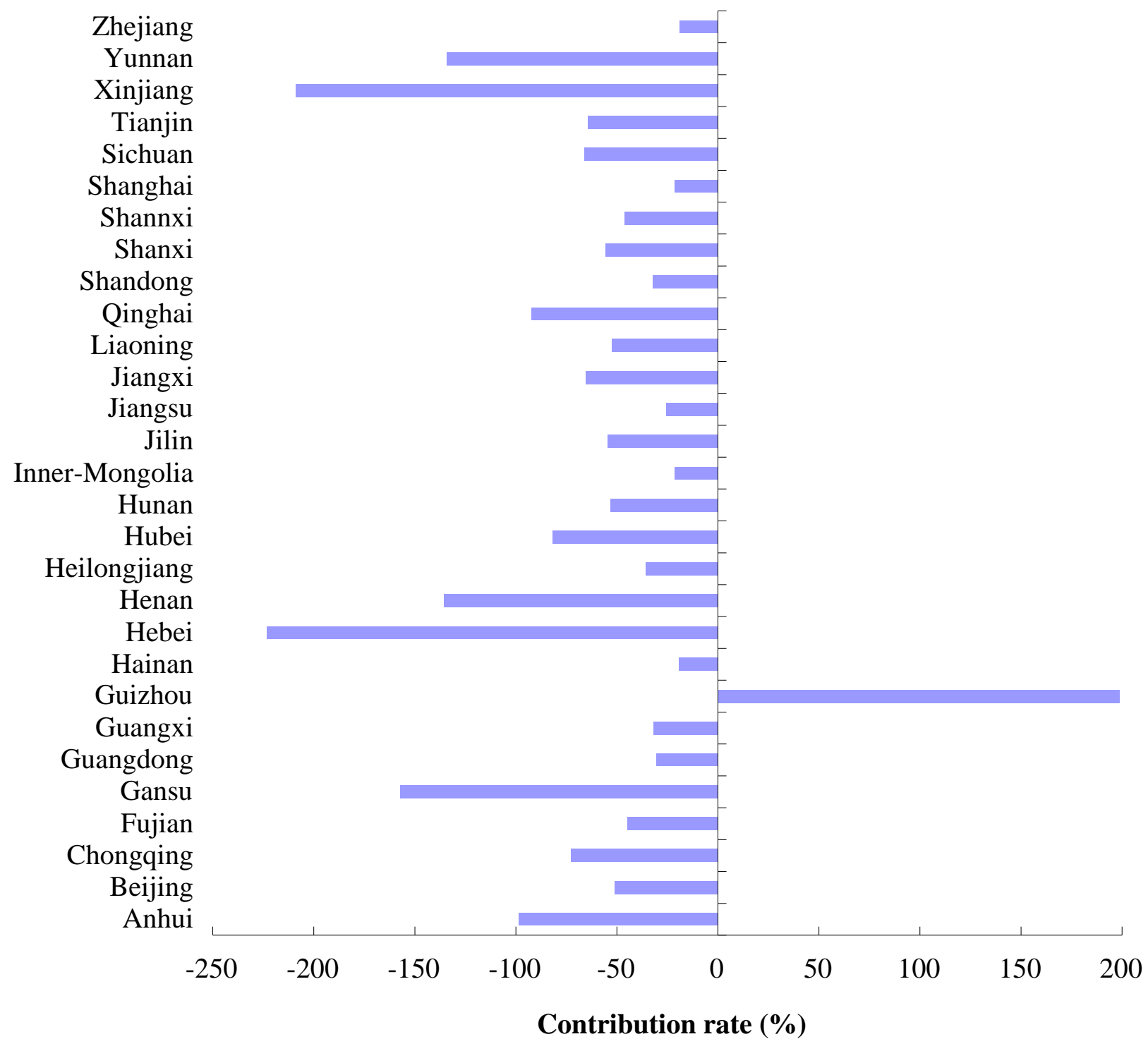

Sources: Authors' own calculation

Figure 5 The contribution rate of the change in energy price 


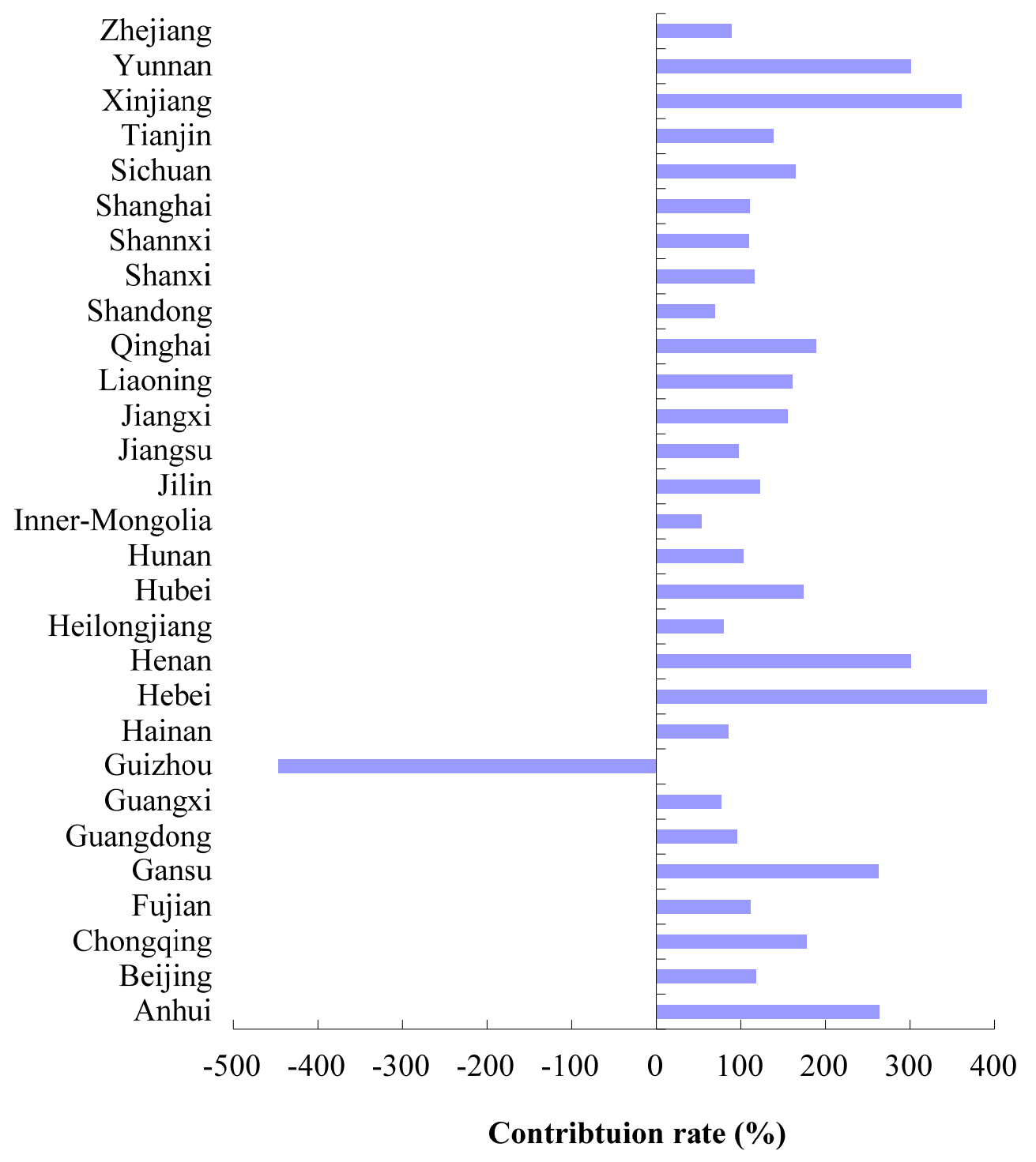

Sources: Authors' own calculation

Figure 6 The contribution rate of the change in residents' per capita consumption expenditure

Figure 7 exhibits the contribution rates of the effect of change in the share of energy consumption in total consumption expenditure and there is a great discrepancy among regions from 2000 to 2010. Most of these rates were positive, indicating that the growth in this share led to an emission increase. The three most affected provinces are Xinjiang, Tianjin and Jiangsu where the increase of carbon emissions caused by the rise of 
residents’ per capita consumption expenditure definitely hindered the reduction of local residents’ carbon emissions.

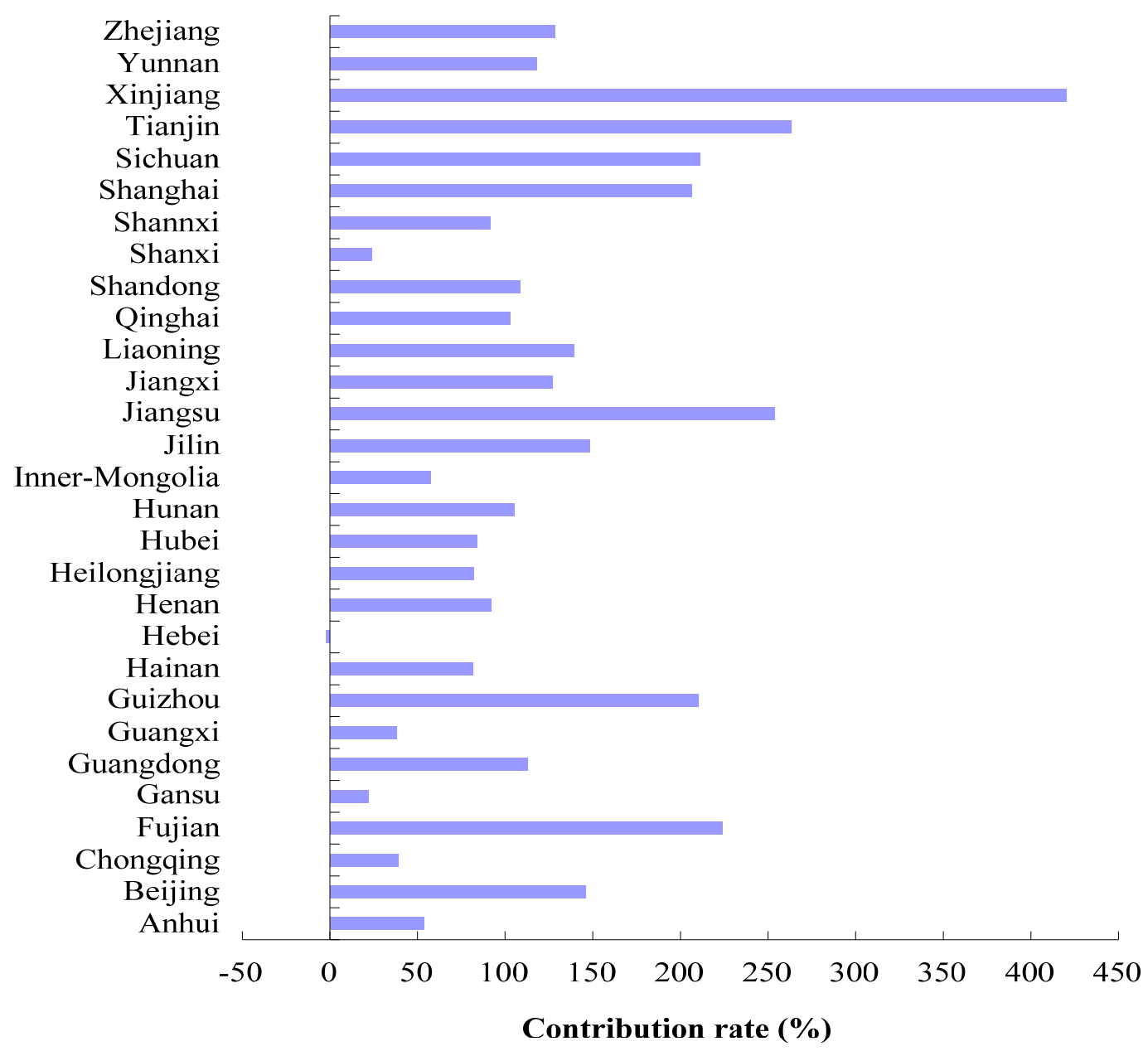

Sources: Authors' own calculation

Figure 7 The contribution rate of the change in the share of energy consumption in total consumption expenditure

There were differences among these provinces concerning the contribution rates of the effect of change in urban and rural population structure during 2000-2010 (see Figure 8). Most of these values are positive, indicating a contribution to the increase in carbon emissions. In view of the effect of change in the urban and rural structure of the 
population, Anhui, Hebei and Xinjiang were the top three provinces where the change in the structure led to an increase of local residential carbon emissions, with the contribution rates of $57.5 \%, 45 \%$ and $32.4 \%$ respectively. Urbanization of these provinces promoted energy consumption and carbon emissions. Inversely, the change in urban and rural population structure slowed down the $\mathrm{CO}_{2}$ emissions in Shanghai, Beijing and Hunan, with the contribution rates of $-11.5 \%,-8.5 \%$ and $-0.3 \%$, respectively.

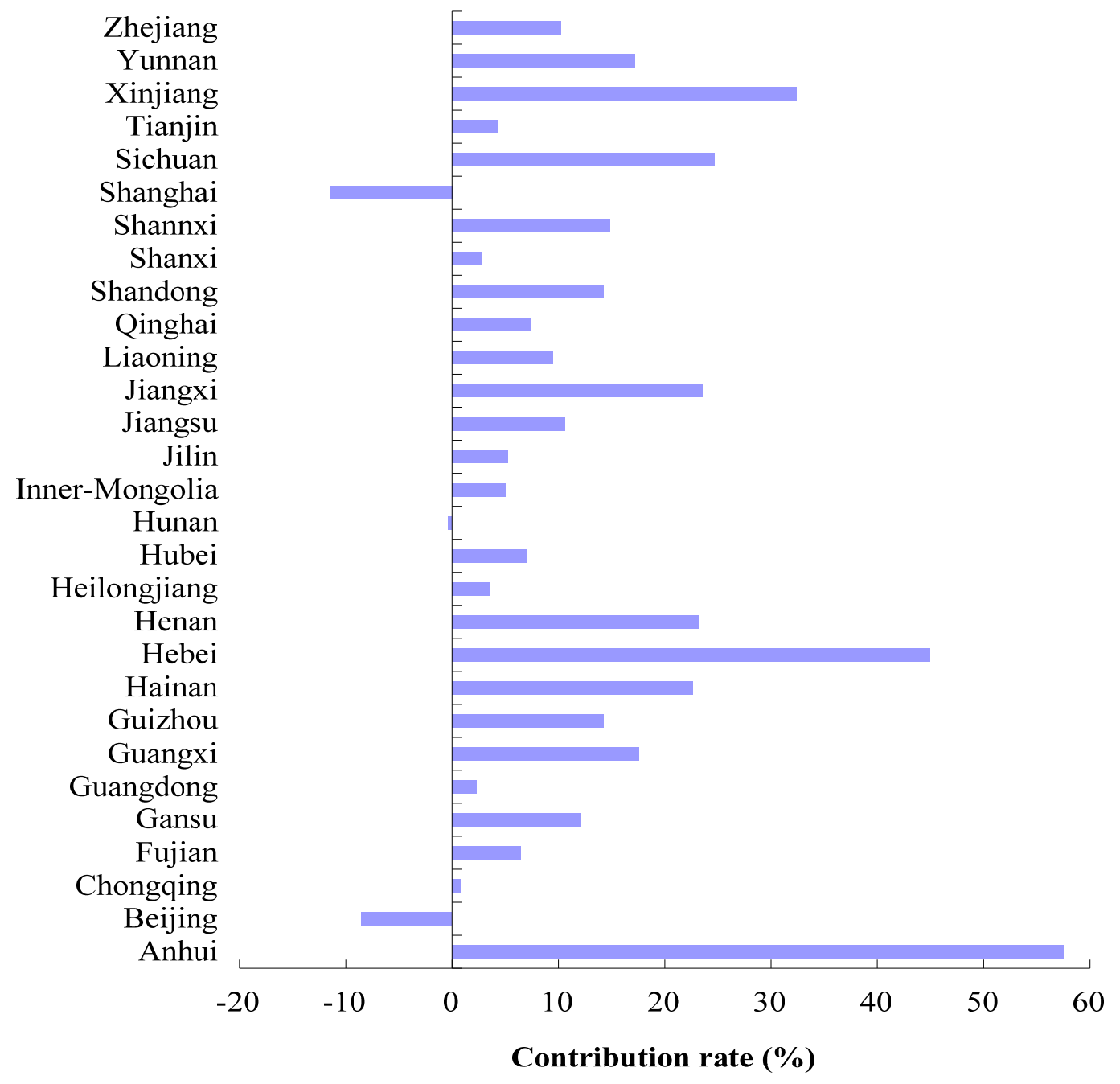

Sources: Authors' own calculation

Figure 8 The contribution rate of the change in urban and rural population structure 
Figure 9 illustrates that the contribution rates of the effect of change in population scale vary considerably among regions during the period of 2000-2010. An overwhelming majority of these rates is positive, indicating an increase in carbon emissions. The top three provinces are Xinjiang, Beijing and Shanghai, where the change in population caused a rise in local residential carbon emissions, with the contribution rates being $66.9 \%, 48.2 \%$ and $41.8 \%$ respectively. On the contrary, the contribution rates of Sichuan, Anhui and Henan provinces are negative, which might be caused by the decrease or slow-growth of the population.

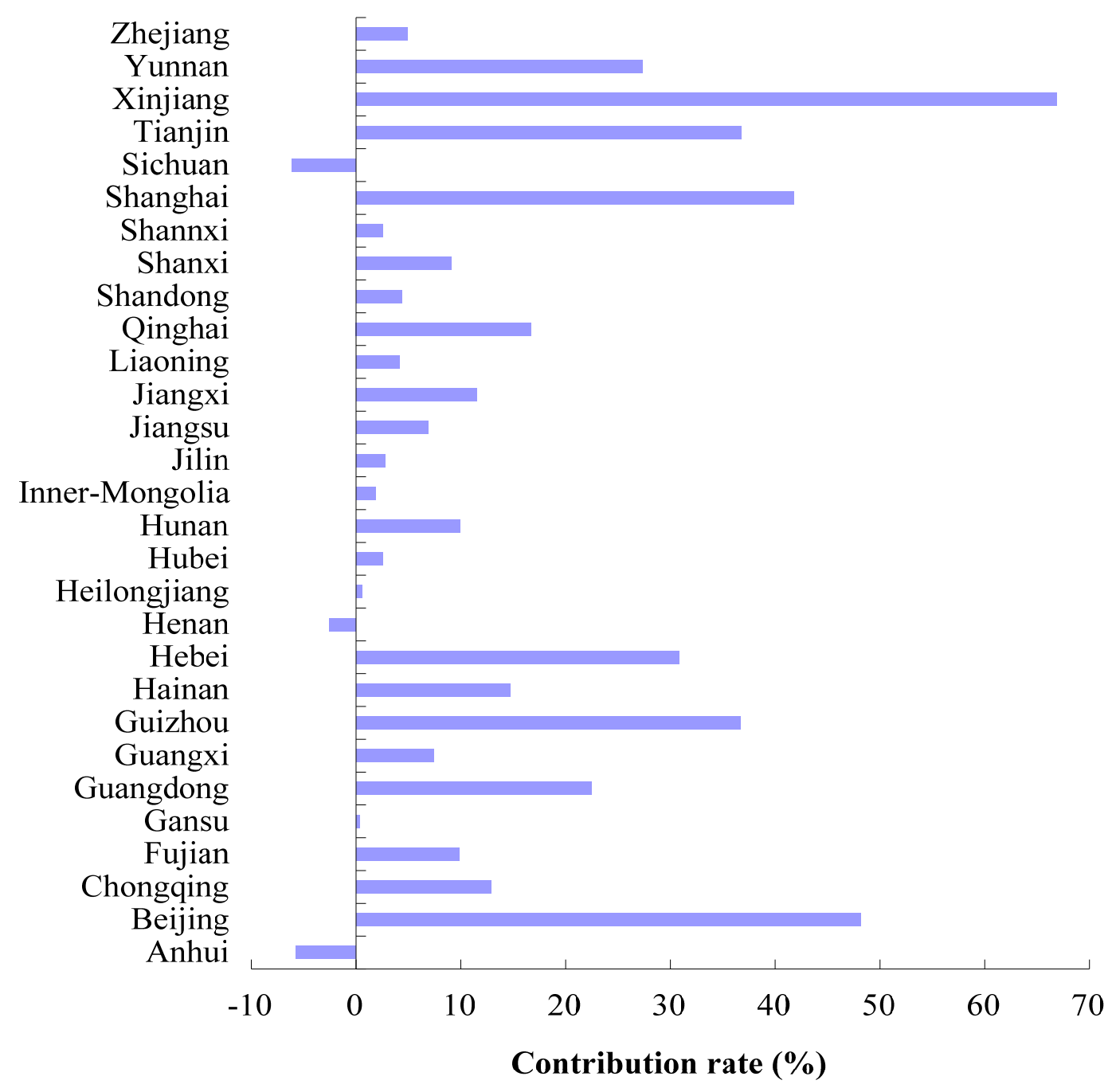

Sources: Authors' own calculation

Figure 9 The contribution rate of the change in population scale 


\section{CONCLUSION AND POLICY IMPLICATIONS}

This paper applied the LMDI method to decompose China's household energy-related $\mathrm{CO}_{2}$ emissions during 2000-2010. As a demand-side analysis, the results help the understanding of the driving forces of carbon emissions from residential energy consumption and can consequently contribute to the discussion about mitigation policies. Specifically, this study showed the change of household $\mathrm{CO}_{2}$ emissions from four aspects (total amount, per capita, urban and rural residents) and illustrated the growing trend during the past decade, with the total and per capita emissions rising from 326.61 megatons and 0.26 ton/person to 670.53 megatons and 0.50 ton/person. This study then investigated the driving factors for the growth of carbon emissions from residents' energy consumption in China. It was found that the growth of per capita consumption expenditure and ratio of energy consumption expenditure in total consumption were the two main factors for the increase of household carbon emissions, while the change of population structure and scale showed a relatively minor effect. On the contrary, the change of energy consumption structure and energy price slowed the growth rate of carbon emissions. In addition, we also studied the different influences of these factors on household carbon emissions in China's provinces. The LMDI decomposition results showed that the regional differences were obvious for all the factors. Thus Chinese authorities should make policies according to local characteristics and implement pertinent policies with high effectiveness and efficiency. It is noted that this study calculated carbon emissions from residential energy consumption based on aggregate statistics. Since residential energy consumption is highly related to residents’ 
daily behaviors, future research should take into account of consumer behaviors and examine household energy consumption more accurately from a microcosmic point of view.

The rise in per capita consumption expenditure and ratio of energy consumption expenditure in total consumption reflected that residents consumed more energy as a result of using more energy-intensive and high-emission commodities nowadays. Therefore, it is necessary to take the environmental impact of household consumption into consideration and guide consumers toward choosing less carbon-intensive products and services, especially in high income provinces. In addition, the government could implement policies such as labeling and green levy programs which tax carbonintensive products, and encourage life style changes and consumer behavior towards more use of public transports more and energy-saving household appliances. During the past few years the Chinese government has carried out a series of policies to improve energy efficiency in vehicles and electrical appliances such as mandatory national fuel consumption standard and minimum energy efficiency standards for eight types of appliance products (Wang et al., 2010). More stringent policies could be implemented to further improve energy efficiency given that there are still significant efficiency gaps (Zhao et al., 2012). Only by adjusting energy consumption behavior reasonably can we mitigate domestic carbon emissions. 
Among other factors, the change of energy consumption structure from low efficiency energy to high efficiency energy plays a crucial role in reducing household carbon emissions. However, the high ratio (more than 80\%) of carbon emissions from coal consumption reveals that the structure optimization of household energy is still a formidable task for China. Since the share of natural gas consumption is too low and rural areas rely predominantly upon coal, greater efforts should be made to exploit clean energies and change the energy consumption structure further, particularly in rural regions. In addition, while less developed western provinces could optimize their energy consumption structure by reducing coal consumption the rich eastern provinces could reduce their energy intensity by the adoption of energy-saving technology (Wu, 2012). Thus, the role of new technology should be better applied to improve energy efficiency and hence reduce energy intensity. The energy price also contributes to carbon emissions reduction, which illustrates that the rise in price urges residents to change their life styles and consumption habits to reduce their spending on energy. Furthermore, $\mathrm{Wu}$ (2012) found that energy intensity is responsive to energy prices in both the short run and the long run. Thus the introduction of an appropriate energypricing mechanism is important for reducing energy consumption and hence emissions in China. Recently, China has proposed a tiered residential electricity price scheme, which is aimed at reinforcing the effects of price leverage on energy consumption and promoting residential electricity conservation. This policy should therefore be encouraged and adopted widely in the country. 


\section{Appendix}

- The effect of change in $\mathrm{CO}_{2}$ emission factor

$$
\Delta C_{i, f_{k}}=\sum_{j} \sum_{k}\left(\frac{C_{i}^{t}-C_{i}^{t-1}}{\ln C_{i}^{t}-\ln C_{i}^{t-1}} \bullet \ln \frac{f_{k}^{t}}{f_{k}^{t-1}}\right)
$$

- The effect of change in energy consumption structure

$$
\Delta C_{i, S_{i, j, k}}=\sum_{j} \sum_{k}\left(\frac{C_{i}^{t}-C_{i}^{t-1}}{\ln C_{i}^{t}-\ln C_{i}^{t-1}} \bullet \ln \frac{S_{i, j, k}^{t}}{S_{i, j, k}^{t}}\right)
$$

- The effect of change in energy price

$$
\Delta C_{i, p e_{i, j}}=\sum_{j} \sum_{k}\left(\frac{C_{i}^{t}-C_{i}^{t-1}}{\ln C_{i}^{t}-\ln C_{i}^{t-1}} \bullet \ln \frac{p e_{i, j}^{t}}{p e_{i, j}^{t-1}}\right)
$$

- The effect of change in share of energy consumption expenditure in total consumption expenditure

$$
\Delta C_{i, \varphi_{i, j}}=\sum_{j} \sum_{k}\left(\frac{C_{i}^{t}-C_{i}^{t-1}}{\ln C_{i}^{t}-\ln C_{i}^{t-1}} \bullet \ln \frac{\varphi_{i, j}^{t}}{\varphi_{i, j}^{t-1}}\right)
$$

- The effect of change in per capita consumption level

$$
\Delta C_{i, V_{i, j}}=\sum_{j} \sum_{k}\left(\frac{C_{i}^{t}-C_{i}^{t-1}}{\ln C_{i}^{t}-\ln C_{i}^{t-1}} \bullet \ln \frac{V_{i, j}^{t}}{\mathrm{v}_{i, j}^{t-1}}\right)
$$

- The effect of change in urban and rural structure of the population

$$
\Delta C_{i, d_{i}}=\sum_{j} \sum_{k}\left(\frac{C_{i}^{t}-C_{i}^{t-1}}{\ln C_{i}^{t}-\ln C_{i}^{t-1}} \bullet \ln \frac{d_{i}^{t}}{\mathrm{~d}_{i}^{t-1}}\right)
$$

- The effect of change in population scale

$$
\Delta C_{i, P_{i}}=\sum_{j} \sum_{k}\left(\frac{C_{i}^{t}-C_{i}^{t-1}}{\ln C_{i}^{t}-\ln C_{i}^{t-1}} \bullet \ln \frac{P_{i}^{t}}{P_{i}^{t-1}}\right)
$$




\section{References}

Achão C., Schaeffer R., Decomposition analysis of the variations in residential electricity consumption in Brazil for the 1980-2007 period: Measuring the activity, intensity and structure effects, Energy policy, 2009, 37(12), 5208-5220.

Andreoni V., Galmarini S., Decoupling economic growth from carbon dioxide emissions: A decomposition analysis of Italian energy consumption, Energy, 2012, 44(1), 682-691.

Ang, B.W., Liu, F.L., Chew, E.P., Perfect decomposition techniques in energy and environmental analysis., Energy Policy, 2003, 31,1561-1566.

Ang, B.W., Decomposition analysis for policy making in energy: which is the preferred method? Energy Policy, 2003, 32, 1131-1139.

Ang, B.W., Liu, N., Energy decomposition analysis: IEA model versus other methods. Viewpoint, Energy Policy, 2007, 35, 1426-1432.

Bin, S., Dowlatabadi, H., Consumer lifestyle approach to US energy use and the related $\mathrm{CO}_{2}$ emissions, Energy Policy , 2005, 33 (2), 197-208.

Cohen, C., Lenzen, M., Schaeffer, R., Energy requirements of households in Brazil, Energy Policy, 205, 33, 555-562.

Energy Research Institute of Chinese National Development and Reform Commission, 2003. Study on the Sustainable Energy Development and Carbon Emission Scenarios Analysis in China.

Feng, Z.H., Zou, L.L., Wei, Y.M., The impact of household consumption on energy use and $\mathrm{CO}_{2}$ emissions in China, Energy, 2011, 36, 656-670. 
Guan, D.B., Peters, G.P., Weber, C.L., Hubacek, K., Journey to world top emitter: An analysis of the driving forces of China's recent $\mathrm{CO}_{2}$ emissions surge. Geophysical Research Letters, 2009, 36( 4).

Hasanbeigi A., Can S. D. R. D., Sathaye J., Analysis and decomposition of the energy intensity of California industries, Energy policy, 2012, 46, 234-245.

IPCC, 2001. Houghton, J.T., Ding, Y., Griggs, D.J., Noguer, M., van der Linden, P.J., Xiaosu, D. (Eds.), Climate Change 2001: The Scientific Basis. Contribution of Working Group I to the Third Assessment Report of the Intergovernmental Panel on Climate Change. Cambridge University Press, Cambridge, UK.

IPCC-The Intergovernmental Panel on Climate Change, 2006. Guidelines for national greenhouse gas inventories, prepared by the national greenhouse gas inventories programme. In: Eggleston, H.S., Buendia, L., Miwa, K., Ngara, T., Tanabe, K.(Eds), IGES, Japan.

Kim, S.H., Korean energy demand in the new millennium:outlook and policy implications, 2000-2005, Fuel and Energy Abstracts, 2002, 43(4), 294.

Lindén, A.L.,Kanyama, A.C., Eriksson, B., Efficient and inefficient aspects of residential energy behaviour: What are the policy instruments for change? Energy Policy, 2006, 34(14), 1918-1927.

Liu, L.C., Wu, G., Wang, J.N., Wei, Y.M., China’s carbon emissions from urban and rural households during 1992-2007, Journal of Cleaner Production, 2011, 19 : 1754-1762. 
Pachauri, S., Spreng, D., Direct and indirect energy requirements of households in India, Energy Policy, 2002, 30(6) ,511-523.

Pachauri, S., An analysis of cross-sectional variations in total household energy, Energy Policy , 2004, 32, 1723-1735.

Park, H.-C., Heo, E., The direct and indirect household energy requirements in the Republic of Korea from 1980 to 2000-An input-output analysis, Energy Policy, 2007, 35 (5), 2839 - 2851.

Reinders, A.H.M.E., Vringer, K., Blok, K., The direct and indirect energy requirement of households in the European Union, Energy Policy, 2003, 31(2), 139-153.

Steg, L., Promoting household energy conservation, Energy Policy, 2008, 36(12), 44494453.

Schipper, L., Bartlett, S., Hawk, D., Vine, E., Linking life-styles and energy use: a matter of time? Annual Review of Energy, 1989, 11(14), 273-320.

Vringer, K., Blok, K., The direct and indirect energy requirements of households in the Netherlands, Energy Policy, 1995, 23(10), 893-910.

Wang, C., Chen, J.g., Zou, J., Decomposition of energy-related $\mathrm{CO}_{2}$ emission in China: 1957-2000, Energy, 2005, 30 (1) , 73-83.

Wang, Z., Jin, Y., Wang, M., Wu, W., New fuel consumption standards for Chinese passenger vehicles and their effects on reductions of oil use and $\mathrm{CO}_{2}$ emissions of the Chinese passenger vehicle fleet, Energy Policy, 2010, 38, 5242-5250.

Weber, C., Perrels, A., Modeling lifestyle effects on energy demand and related emissions, Energy Policy, 2000, 28, 549-66. 
Wei, Y.M., Liu, L.C., Fan, Y., Wu, G., The impact of lifestyle on energy use and $\mathrm{CO}_{2}$ emission: an empirical analysis of China’s residents, Energy Policy, 2007, 35, 24757.

Wu Y. R., Energy intensity and its determinants in China’s regional economies, Energy Policy, 2012, 41, 703-711.

Zha, D.L., Zhou, D.Q., Zhou, P., Driving forces of residential $\mathrm{CO}_{2}$ emissions in urban and rural China: An index decomposition analysis, Energy Policy, 2010, 38(7), 3377-3383.

Zhao, X.L., Li, N., Ma, C.B., Residential energy consumption in urban China: A decomposition analysis, Energy Policy, 2012, 41, 644-653.

Zhou, N., McNeil, Michael A., Levine, Mark, 2009. Energy for 500 Million Homes: Divers and Outlooks for Residential Energy Consumption in China. Environmental Energy Technologies Division, Ernest Orlando Lawrence Berkeley National Laboratory 
Editor, UWA Economics Discussion Papers:

Ernst Juerg Weber

Business School - Economics

University of Western Australia

35 Sterling Hwy

Crawley WA 6009

Australia

Email: ecoadmin@biz.uwa.edu.au

The Economics Discussion Papers are available at:

1980 - 2002: http://ecompapers.biz.uwa.edu.au/paper/PDF\%20of\%20Discussion\%20Papers/

Since 2001: http://ideas.repec.org/s/uwa/wpaper1.html

Since 2004: $\quad$ http://www.business.uwa.edu.au/school/disciplines/economics

\begin{tabular}{|c|c|c|}
\hline \multicolumn{3}{|c|}{$\begin{array}{l}\text { ECONOMICS DISCUSSION PAPERS } \\
2012\end{array}$} \\
\hline $\begin{array}{l}\text { DP } \\
\text { NUMBER }\end{array}$ & AUTHORS & TITLE \\
\hline 12.01 & $\begin{array}{l}\text { Clements, K.W., Gao, G., and } \\
\text { Simpson, T. }\end{array}$ & $\begin{array}{l}\text { DISPARITIES IN INCOMES AND PRICES } \\
\text { INTERNATIONALLY }\end{array}$ \\
\hline 12.02 & Tyers, R. & $\begin{array}{l}\text { THE RISE AND ROBUSTNESS OF ECONOMIC FREEDOM } \\
\text { IN CHINA }\end{array}$ \\
\hline 12.03 & Golley, J. and Tyers, R. & $\begin{array}{l}\text { DEMOGRAPHIC DIVIDENDS, DEPENDENCIES AND } \\
\text { ECONOMIC GROWTH IN CHINA AND INDIA }\end{array}$ \\
\hline 12.04 & Tyers, R. & LOOKING INWARD FOR GROWTH \\
\hline 12.05 & Knight, K. and McLure, M. & THE ELUSIVE ARTHUR PIGOU \\
\hline 12.06 & McLure, M. & $\begin{array}{l}\text { ONE HUNDRED YEARS FROM TODAY: A. C. PIGOU'S } \\
\text { WEALTH AND WELFARE }\end{array}$ \\
\hline 12.07 & Khuu, A. and Weber, E.J. & HOW AUSTRALIAN FARMERS DEAL WITH RISK \\
\hline 12.08 & Chen, M. and Clements, K.W. & PATTERNS IN WORLD METALS PRICES \\
\hline 12.09 & Clements, K.W. & UWA ECONOMICS HONOURS \\
\hline 12.10 & Golley, J. and Tyers, R. & $\begin{array}{l}\text { CHINA'S GENDER IMBALANCE AND ITS ECONOMIC } \\
\text { PERFORMANCE }\end{array}$ \\
\hline 12.11 & Weber, E.J. & $\begin{array}{l}\text { AUSTRALIAN FISCAL POLICY IN THE AFTERMATH OF } \\
\text { THE GLOBAL FINANCIAL CRISIS }\end{array}$ \\
\hline 12.12 & Hartley, P.R. and Medlock III, K.B. & $\begin{array}{l}\text { CHANGES IN THE OPERATIONAL EFFICIENCY OF } \\
\text { NATIONAL OIL COMPANIES }\end{array}$ \\
\hline 12.13 & Li, L. & $\begin{array}{l}\text { HOW MUCH ARE RESOURCE PROJECTS WORTH? A } \\
\text { CAPITAL MARKET PERSPECTIVE }\end{array}$ \\
\hline
\end{tabular}




\begin{tabular}{|c|c|c|}
\hline 12.14 & Chen, A. and Groenewold, N. & $\begin{array}{l}\text { THE REGIONAL ECONOMIC EFFECTS OF A } \\
\text { REDUCTION IN CARBON EMISSIONS AND AN } \\
\text { EVALUATION OF OFFSETTING POLICIES IN CHINA }\end{array}$ \\
\hline 12.15 & Collins, J., Baer, B. and Weber, E.J. & $\begin{array}{l}\text { SEXUAL SELECTION, CONSPICUOUS CONSUMPTION } \\
\text { AND ECONOMIC GROWTH }\end{array}$ \\
\hline 12.16 & Wu, Y. & TRENDS AND PROSPECTS IN CHINA’S R\&D SECTOR \\
\hline 12.17 & Cheong, T.S. and $\mathrm{Wu}, \mathrm{Y}$. & $\begin{array}{l}\text { INTRA-PROVINCIAL INEQUALITY IN CHINA: AN } \\
\text { ANALYSIS OF COUNTY-LEVEL DATA }\end{array}$ \\
\hline 12.18 & Cheong, T.S. & THE PATTERNS OF REGIONAL INEQUALITY IN CHINA \\
\hline 12.19 & Wu, Y. & $\begin{array}{l}\text { ELECTRICITY MARKET INTEGRATION: GLOBAL } \\
\text { TRENDS AND IMPLICATIONS FOR THE EAS REGION }\end{array}$ \\
\hline 12.20 & Knight, K. & $\begin{array}{l}\text { EXEGESIS OF DIGITAL TEXT FROM THE HISTORY OF } \\
\text { ECONOMIC THOUGHT: A COMPARATIVE } \\
\text { EXPLORATORY TEST }\end{array}$ \\
\hline 12.21 & Chatterjee, I. & $\begin{array}{l}\text { COSTLY REPORTING, EX-POST MONITORING, AND } \\
\text { COMMERCIAL PIRACY: A GAME THEORETIC } \\
\text { ANALYSIS }\end{array}$ \\
\hline 12.22 & Pen, S.E. & QUALITY-CONSTANT ILLICIT DRUG PRICES \\
\hline 12.23 & Cheong, T.S. and Wu, Y. & $\begin{array}{l}\text { REGIONAL DISPARITY, TRANSITIONAL DYNAMICS } \\
\text { AND CONVERGENCE IN CHINA }\end{array}$ \\
\hline 12.24 & Ezzati, P. & $\begin{array}{l}\text { FINANCIAL MARKETS INTEGRATION OF IRAN } \\
\text { WITHIN THE MIDDLE EAST AND WITH THE REST OF } \\
\text { THE WORLD }\end{array}$ \\
\hline 12.25 & Kwan, F., Wu, Y. and Zhuo, S. & $\begin{array}{l}\text { RE-EXAMINATION OF THE SURPLUS AGRICULTURAL } \\
\text { LABOUR IN CHINA }\end{array}$ \\
\hline 12.26 & Wu, Y. & R\&D BEHAVIOUR IN CHINESE FIRMS \\
\hline 12.27 & Tang, S.H.K. and Yung, L.C.W. & $\begin{array}{l}\text { MAIDS OR MENTORS? THE EFFECTS OF LIVE-IN } \\
\text { FOREIGN DOMESTIC WORKERS ON SCHOOL } \\
\text { CHILDREN'S EDUCATIONAL ACHIEVEMENT IN HONG } \\
\text { KONG }\end{array}$ \\
\hline 12.28 & Groenewold, N. & $\begin{array}{l}\text { AUSTRALIA AND THE GFC: SAVED BY ASTUTE } \\
\text { FISCAL POLICY? }\end{array}$ \\
\hline
\end{tabular}




\begin{tabular}{|c|c|c|}
\hline \multicolumn{3}{|c|}{$\begin{array}{l}\text { ECONOMICS DISCUSSION PAPERS } \\
2013\end{array}$} \\
\hline $\begin{array}{l}\text { DP } \\
\text { NUMBER }\end{array}$ & AUTHORS & TITLE \\
\hline 13.01 & $\begin{array}{l}\text { Chen, M., Clements, K.W. and } \\
\text { Gao, G. }\end{array}$ & THREE FACTS ABOUT WORLD METAL PRICES \\
\hline 13.02 & Collins, J. and Richards, O. & $\begin{array}{l}\text { EVOLUTION, FERTILITY AND THE AGEING } \\
\text { POPULATION }\end{array}$ \\
\hline 13.03 & $\begin{array}{l}\text { Clements, K., Genberg, H., } \\
\text { Harberger, A., Lothian, J., } \\
\text { Mundell, R., Sonnenschein, H. and } \\
\text { Tolley, G. }\end{array}$ & LARRY SJAASTAD, 1934-2012 \\
\hline 13.04 & Robitaille, M.C. and Chatterjee, I. & MOTHERS-IN-LAW AND SON PREFERENCE IN INDIA \\
\hline 13.05 & Clements, K.W. and Izan, I.H.Y. & $\begin{array}{l}\text { REPORT ON THE } 25^{\mathrm{TH}} \text { PHD CONFERENCE IN } \\
\text { ECONOMICS AND BUSINESS }\end{array}$ \\
\hline 13.06 & Walker, A. and Tyers, R. & QUANTIFYING AUSTRALIA’S “THREE SPEED” BOOM \\
\hline 13.07 & Yu, F. and Wu, Y. & PATENT EXAMINATION AND DISGUISED PROTECTION \\
\hline 13.08 & $\mathrm{Yu}, \mathrm{F}$. and $\mathrm{Wu}, \mathrm{Y}$. & $\begin{array}{l}\text { PATENT CITATIONS AND KNOWLEDGE SPILLOVERS: } \\
\text { AN ANALYSIS OF CHINESE PATENTS REGISTER IN } \\
\text { THE US }\end{array}$ \\
\hline 13.09 & Chatterjee, I. and Saha, B. & BARGAINING DELEGATION IN MONOPOLY \\
\hline 13.10 & Cheong, T.S. and Wu, Y. & $\begin{array}{l}\text { GLOBALIZATION AND REGIONAL INEQUALITY IN } \\
\text { CHINA }\end{array}$ \\
\hline 13.11 & Cheong, T.S. and Wu, Y. & INEQUALITY AND CRIME RATES IN CHINA \\
\hline 13.12 & Robertson, P.E. and Ye, L. & ON THE EXISTENCE OF A MIDDLE INCOME TRAP \\
\hline 13.13 & Robertson, P.E. & THE GLOBAL IMPACT OF CHINA’S GROWTH \\
\hline 13.14 & $\begin{array}{l}\text { Hanaki, N., Jacquemet, N., } \\
\text { Luchini, S., and Zylbersztejn, A. }\end{array}$ & $\begin{array}{l}\text { BOUNDED RATIONALITY AND STRATEGIC } \\
\text { UNCERTAINTY IN A SIMPLE DOMINANCE SOLVABLE } \\
\text { GAME }\end{array}$ \\
\hline 13.15 & $\begin{array}{l}\text { Okatch, Z., Siddique, A. and } \\
\text { Rammohan, A. }\end{array}$ & $\begin{array}{l}\text { DETERMINANTS OF INCOME INEQUALITY IN } \\
\text { BOTSWANA }\end{array}$ \\
\hline 13.16 & Clements, K.W. and Gao, G. & $\begin{array}{l}\text { A MULTI-MARKET APPROACH TO MEASURING THE } \\
\text { CYCLE }\end{array}$ \\
\hline 13.17 & Chatterjee, I. and Ray, R. & $\begin{array}{l}\text { THE ROLE OF INSTITUTIONS IN THE INCIDENCE OF } \\
\text { CRIME AND CORRUPTION }\end{array}$ \\
\hline 13.18 & Fu, D. and Wu, Y. & $\begin{array}{l}\text { EXPORT SURVIVAL PATTERN AND DETERMINANTS } \\
\text { OF CHINESE MANUFACTURING FIRMS }\end{array}$ \\
\hline 13.19 & Shi, X., Wu, Y. and Zhao, D. & $\begin{array}{l}\text { KNOWLEDGE INTENSIVE BUSINESS SERVICES AND } \\
\text { THEIR IMPACT ON INNOVATION IN CHINA }\end{array}$ \\
\hline 13.20 & $\begin{array}{l}\text { Tyers, R., Zhang, Y. and } \\
\text { Cheong, T.S. }\end{array}$ & $\begin{array}{l}\text { CHINA'S SAVING AND GLOBAL ECONOMIC } \\
\text { PERFORMANCE }\end{array}$ \\
\hline 13.21 & Collins, J., Baer, B. and Weber, E.J. & $\begin{array}{l}\text { POPULATION, TECHNOLOGICAL PROGRESS AND THE } \\
\text { EVOLUTION OF INNOVATIVE POTENTIAL }\end{array}$ \\
\hline 13.22 & Hartley, P.R. & THE FUTURE OF LONG-TERM LNG CONTRACTS \\
\hline 13.23 & Tyers, R. & $\begin{array}{l}\text { A SIMPLE MODEL TO STUDY GLOBAL } \\
\text { MACROECONOMIC INTERDEPENDENCE }\end{array}$ \\
\hline
\end{tabular}




\begin{tabular}{|c|c|c|}
\hline 13.24 & McLure, M. & $\begin{array}{l}\text { REFLECTIONS ON THE QUANTITY THEORY: PIGOU IN } \\
1917 \text { AND PARETO IN 1920-21 }\end{array}$ \\
\hline 13.25 & Chen, A. and Groenewold, N. & $\begin{array}{l}\text { REGIONAL EFFECTS OF AN EMISSIONS-REDUCTION } \\
\text { POLICY IN CHINA: THE IMPORTANCE OF THE } \\
\text { GOVERNMENT FINANCING METHOD }\end{array}$ \\
\hline 13.26 & Siddique, M.A.B. & $\begin{array}{l}\text { TRADE RELATIONS BETWEEN AUSTRALIA AND } \\
\text { THAILAND: } 1990 \text { TO } 2011\end{array}$ \\
\hline 13.27 & Li, B. and Zhang, J. & $\begin{array}{l}\text { GOVERNMENT DEBT IN AN INTERGENERATIONAL } \\
\text { MODEL OF ECONOMIC GROWTH, ENDOGENOUS } \\
\text { FERTILITY, AND ELASTIC LABOR WITH AN } \\
\text { APPLICATION TO JAPAN }\end{array}$ \\
\hline 13.28 & Robitaille, M. and Chatterjee, I. & $\begin{array}{l}\text { SEX-SELECTIVE ABORTIONS AND INFANT } \\
\text { MORTALITY IN INDIA: THE ROLE OF PARENTS' } \\
\text { STATED SON PREFERENCE }\end{array}$ \\
\hline 13.29 & Ezzati, P. & $\begin{array}{l}\text { ANALYSIS OF VOLATILITY SPILLOVER EFFECTS: } \\
\text { TWO-STAGE PROCEDURE BASED ON A MODIFIED } \\
\text { GARCH-M }\end{array}$ \\
\hline 13.30 & Robertson, P. E. & $\begin{array}{l}\text { DOES A FREE MARKET ECONOMY MAKE AUSTRALIA } \\
\text { MORE OR LESS SECURE IN A GLOBALISED WORLD? }\end{array}$ \\
\hline 13.31 & $\begin{array}{l}\text { Das, S., Ghate, C. and } \\
\text { Robertson, P. E. }\end{array}$ & $\begin{array}{l}\text { REMOTENESS AND UNBALANCED GROWTH: } \\
\text { UNDERSTANDING DIVERGENCE ACROSS INDIAN } \\
\text { DISTRICTS }\end{array}$ \\
\hline 13.32 & Robertson, P.E. and Sin, A. & $\begin{array}{l}\text { MEASURING HARD POWER: CHINA'S ECONOMIC } \\
\text { GROWTH AND MILITARY CAPACITY }\end{array}$ \\
\hline 13.33 & Wu, Y. & $\begin{array}{l}\text { TRENDS AND PROSPECTS FOR THE RENEWABLE } \\
\text { ENERGY SECTOR IN THE EAS REGION }\end{array}$ \\
\hline 13.34 & $\begin{array}{l}\text { Yang, S., Zhao, D., Wu, Y. and } \\
\text { Fan, J. }\end{array}$ & $\begin{array}{l}\text { REGIONAL VARIATION IN CARBON EMISSION AND } \\
\text { ITS DRIVING FORCES IN CHINA: AN INDEX } \\
\text { DECOMPOSITION ANALYSIS }\end{array}$ \\
\hline
\end{tabular}




\begin{tabular}{|c|c|c|}
\hline \multicolumn{3}{|c|}{$\begin{array}{c}\text { ECONOMICS DISCUSSION PAPERS } \\
2014\end{array}$} \\
\hline $\begin{array}{l}\text { DP } \\
\text { NUMBER }\end{array}$ & AUTHORS & TITLE \\
\hline 14.01 & $\begin{array}{l}\text { Boediono, Vice President of the Republic } \\
\text { of Indonesia }\end{array}$ & $\begin{array}{l}\text { THE CHALLENGES OF POLICY MAKING IN A } \\
\text { YOUNG DEMOCRACY: THE CASE OF INDONESIA } \\
\text { (52ND SHANN MEMORIAL LECTURE, 2013) }\end{array}$ \\
\hline 14.02 & Metaxas, P.E. and Weber, E.J. & $\begin{array}{l}\text { AN AUSTRALIAN CONTRIBUTION TO } \\
\text { INTERNATIONAL TRADE THEORY: THE } \\
\text { DEPENDENT ECONOMY MODEL }\end{array}$ \\
\hline 14.03 & Fan, J., Zhao, D., Wu, Y. and Wei, J. & $\begin{array}{l}\text { CARBON PRICING AND ELECTRICITY MARKET } \\
\text { REFORMS IN CHINA }\end{array}$ \\
\hline 14.04 & McLure, M. & $\begin{array}{l}\text { A.C. PIGOU'S MEMBERSHIP OF THE } \\
\text { 'CHAMBERLAIN-BRADBURY' COMMITTEE. } \\
\text { PART I: THE HISTORICAL CONTEXT }\end{array}$ \\
\hline 14.05 & McLure, M. & $\begin{array}{l}\text { A.C. PIGOU'S MEMBERSHIP OF THE } \\
\text { 'CHAMBERLAIN-BRADBURY’ COMMITTEE. } \\
\text { PART II: 'TRANSITIONAL’ AND ‘ONGOING' ISSUES }\end{array}$ \\
\hline 14.06 & King, J.E. and McLure, M. & HISTORY OF THE CONCEPT OF VALUE \\
\hline 14.07 & Williams, A. & $\begin{array}{l}\text { A GLOBAL INDEX OF INFORMATION AND } \\
\text { POLITICAL TRANSPARENCY }\end{array}$ \\
\hline 14.08 & Knight, K. & $\begin{array}{l}\text { A.C. PIGOU'S THE THEORY OF UNEMPLOYMENT } \\
\text { AND ITS CORRIGENDA: THE LETTERS OF } \\
\text { MAURICE ALLEN, ARTHUR L. BOWLEY, RICHARD } \\
\text { KAHN AND DENNIS ROBERTSON }\end{array}$ \\
\hline & & \\
\hline & & \\
\hline & & \\
\hline
\end{tabular}

